\title{
Fatigue Strength of Low Carbon Steel SS400 on Pack Carburizing Treatment with Pinctada Maxima Shell Powder Energizer
}

\author{
Sujita Darmo ${ }^{1}$, Yesung Allo Padang ${ }^{2}$ and I Kade Wiratama ${ }^{3}$ \\ Senior Lecturer ${ }^{1-3}$ \\ Department of Mechanical Engineering \\ Mataram University \\ Mataram \\ Indonesia
}

\begin{abstract}
The pack carburizing treatment is done to improve the hardness number of low carbon steel. The surface hardness number is high but the core is ductile. Changes in the surface hardness number affect the strength of fatigue The research has been done by using carburized media of teak wood charcoal (TWC) as the source of carbon element and Pinctada maxima shell powder (PMSP) as the source of Ca element as energizer or catalyst. Alternative carburized media applications are still rarely performed. This study discusses the effects of different carburizer media on the fatigue strength of low carbon steel SS400. The composition of PMSP used: 10, 20 and 30 (\% wt) and composition of teak wood charcoal 90, 80 and 70 (\% wt). Pack carburizing process is done at temperature $800 \mathrm{OC}$ and 950 OC, soaking time 5 hours. Followed the performed Rotating Bending Test, observation with SEM (scanning electron microscope), to know the fatigue strength and microstructure specimens. In conclusion, the Pack carburizing process is done at temperature 950 OC, soaking time for 5 hours, composition media carburizer 30\% PMSP and 70\% TWC can increase the surface hardness number but decrease the cycles number, of fatigue of low carbon steel SS400.
\end{abstract}

Key Words: Pack Caburizing, Hardness Number, Rotating Bending Test, Energizer, Teak Wood Charcoal, Pinctada Maxima Shell Powder, the Cycles Number of Fatigue.

\section{INTRODUCTION}

This Indonesia is famous as a country producing sea pearl species (Pinctada maxima). The Pinctada maxima shell contain calcium tricarbonate $\left(\mathrm{CaCO}_{3}\right)$ (11). which can be used as an alternative energizer in the pack carburization proceses. The heat treatment process to increase the hardness of the low carbon steel surface is carburizing pack. Carburizer media such as teak wood charcoal, coconut shell charcoal, bamboo charcoal and $\mathrm{CaCO}_{3}, \mathrm{BaCO}_{3}, \mathrm{NaCO}_{3}$ as energizer or catalyst (6).The mechanical properties of mild steels (low carbon steels) undergoing pack carburizing processes are influenced by the carburizing temperature, time and post heat treatment (1-4). The research focuses on the effects of the carburizing temperature and time on the mechanical properties of mild steel carburized with activated carbon, at 850,900 and $950{ }^{\circ} \mathrm{C}$, soaked at the carburizing temperature for 15 and 30 minutes, quenched in oil, tempered at $550{ }^{\circ} \mathrm{C}$ and held for 60 minutes. It was concluded that the optimum combination of mechanical properties is achieved at the carburizing temperature of $900{ }^{\circ} \mathrm{C}$ followed by oil quenching and tempering at $550{ }^{\circ} \mathrm{C}$. In this study, various carburizing compounds were used to pack carburizing mild steel. Various weight percentages of cow bone were used as energizer in the carburizing (2-5). The experiment was carried out using a muffle furnace at $900^{\circ} \mathrm{C}$ for $8 \mathrm{~h}$. Hardness tests were taken using Vickers micro-hardness tester. The result showed that 60 weight $\%$ charcoal / 40 weight $\mathrm{t} \%$ cow bone had the best result with an effective case depth of $2.32 \mathrm{~mm}$ produced in the case of the carburized steel. The work showed that cow bone can be used as energizer in pack carburization of mild steel. The hardness profile plot of the 60 weight $\%$ charcoal $/ 40 \%$ cow bone carburized mild steel was also higher than the other composition. This work evaluates the suitability of using palm kernel shell, animal bone (mammalian bones from cattle) and seashell (oyster shell) materials as carburizers for case hardening of $0.078 \% \mathrm{C}$ mild steel. The carburizing media used were milled into fine powder while Barium carbonate (BaCO3) was used as an energizer in the carburizing process $(6,7,16)$. The results of the carbon analysis show that palm kernel shell and animal bone are potentially suitable to be used as a carburizing media than the seashell at high temperatures (above $1000^{\circ} \mathrm{C}$ ) with holding time above 1 hour. The effects of varied carburizing temperatures and holding time on the mechanical properties of AISI/SAE1020 steel have been investigated $(7,12,13)$. Standard test samples prepared from the steel sample were subjected to pack hardening process using carbonized palm kernel shell as a carburizer at $800^{\circ}, 850^{\circ}, 900^{\circ}$ and $950^{\circ} \mathrm{C}$ and held for 60,90 and 120 minutes, quenched in oil and temper at $500^{\circ} \mathrm{C}$ for 60 minutes. The mechanical properties of mild steels were found to be strongly 
influenced by the process of carburization, carburizing temperature and holding time using carbonized palm kernel shell. It was concluded that the optimum combination of mechanical properties is achieved at the carburizing temperature of $950^{\circ} \mathrm{C}$ soaked for 120 minutes followed by oil quenching and tempering at $500^{\circ} \mathrm{C}$ for 60 minutes. The fatigue crack propagation behavior of low alloy steels subjected to case carburization treatment have been done $(8,14)$. These components have to work under fatigue loading during their service life, which occasionally results in fatigue failures. The present work is aimed at investigating the fatigue crack propagation behavior of some commonly used low alloy steels in case carburizing condition. The crack propagation mechanisms were investigated through fractographic observations on the fractured surfaces of standard fatigue test specimens failed under four-point rotating bending fatigue tests. The conclusion is the residual compressive stresses induced during case carburizing the majority of the fatigue cracks was founded to initiate at the surface. Crack initiation was followed by trans granular mode of stable crack propagation for all the steels, while subsequent crack propagation behavior was found to be dependent on the contents of alloying elements in a given steel. Steels containing higher amounts of chromium were found to exhibit greater tendency towards the intergranular decohesion cracking. The fatigue resistance of carburized $16 \mathrm{MnCr} 5$ steel is influenced by study of the effect of austenizing and tempering heat treatment temperatures $(9,10,15)$. The rotating bending fatigue specimens were machined from $16 \mathrm{MnCr}$ (ASTM 5117) steel rod, and pack carburized at $900^{\circ} \mathrm{C}$ for 2 hours soaking time. Carburized specimens were then austenizing at $900^{\circ} \mathrm{C}$ for one hour, water quenched, reaustenizing at temperatures $750^{\circ} \mathrm{C}, 800^{\circ} \mathrm{C}$ and $900^{\circ} \mathrm{C}$ for one hour, then tempered at $200^{\circ} \mathrm{C}$ temperature. Other carburized specimens were tempered by heating to $760^{\circ} \mathrm{C}$ temperature, water quenched to room temperature, then tempered at temperatures $200^{\circ} \mathrm{C}, 300^{\circ} \mathrm{C}$, and $400^{\circ} \mathrm{C}$ for one hour. The specimens were tested by rotating bending fatigue machine up to fracture under different stress levels $(200,250,300,350,400)$ $\mathrm{MPa}$. Experimental results showed that fatigue resistance of the austenizing steel specimens after carburization process has been increased, and the crack length developed on the specimen surfaces was decreased with an increase of the austenizing temperature up to $800^{\circ} \mathrm{C}$. The research described above has not yet discussed the influence of alternative energizer to changes in the strength of fatigue.

\section{METHODE OF RESEARCH}

\subsection{Material}

The speciment used is low carbon steel grade SS400. Their chemical composition as measured by Bruker S1 Turbo SD ( XRF analyzer ) is Fe: 98.11, C: 0.159, Mo: 0.078, Mn: 0.624, Cu: 0.241, Cr: 0.110, Nb: 0.16 and Ti: 0.008 percent. The dimensions of the specimen for fatigue strength test refer to ISO test standard 1143 (1975). as shown in Figure 1. Number of specimens prepared for 18 pieces, adjusted for the variable amount of temperature carburizing, time soaking and composition of the carburizer media.

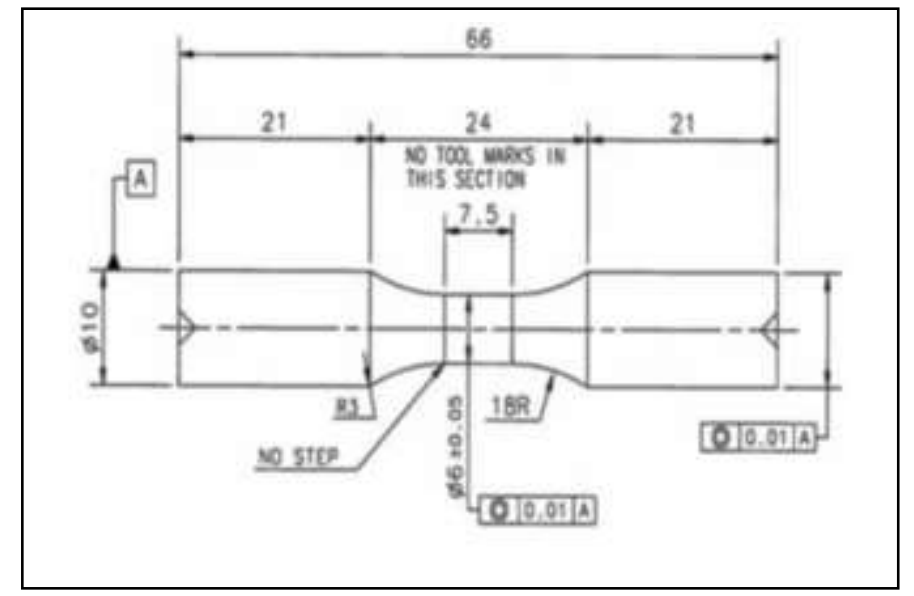

Figure 1. The specimen for rotating bending fatigue test (ISO test standard 1143, 1975)

\subsection{Pack Carburizing Process}

Carburizer media used is teak wood charcoal (TWC) and Picntada maxima shell powder (PMSP) shell powder. Composition of ( PMSP) used : 10, 20 and 30 (\% wt) and TWC used : 90, 80, and 70 (\% wt). Specimen and media carburizer are inserted into the carburizing box which made of low carbon steel. Then heat on the electric furnace, as shown in Figure 2. The carburizing box dimensions with $5 \mathrm{~mm}$ thickness of the plate with a length of $100 \mathrm{~mm}, 100 \mathrm{~mm}$ wide and $100 \mathrm{~mm}$ high. Pack Carburizing is done at temperature $800{ }^{\circ} \mathrm{C}$. and $950{ }^{\circ} \mathrm{C}$ with time soaking 5 hours. Then performed rotating bending test is 
shawn in Figure 3. And observation with SEM (scanning electron microscop), to know the fatigue strength and microstructure specimens..

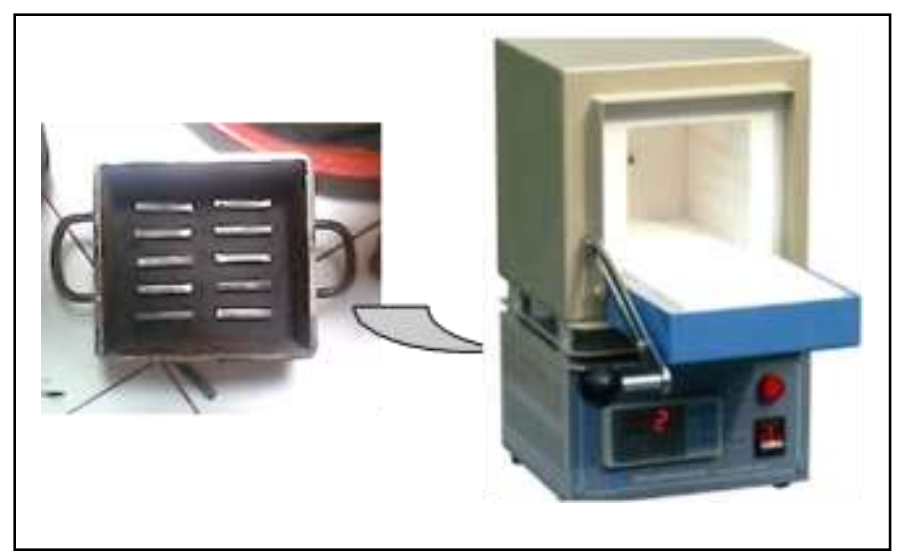

Figure.2. Pack carburizing process

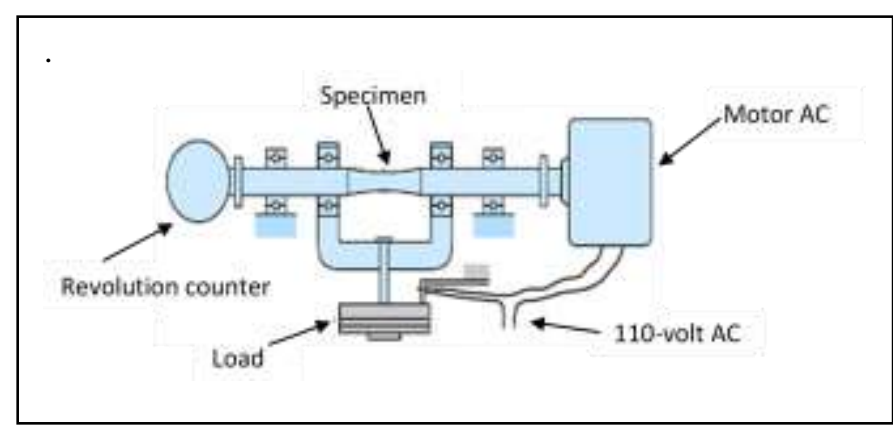

Figure 3.Design moore rotating bending fatigue test

\section{RESULT AND DISCUSSION}

\subsection{Fatigue Strength Testing Result}

Fatigue strength testing by rotating bending fatigue machine up to fracture under different minimum stress levels 275 $390 \mathrm{Mpa}$. The specimens tested were those that had treated a pack carburizing process. Carburizer media used is teak wood charcoal (TWC) and Pinctada Maxima Shell Powder (PMSP). The composition of (PMSP) used: 10, 20 and 30 (\% wt). Pack Carburizing is done at temperature $800{ }^{\circ} \mathrm{C}$ and $950{ }^{\circ} \mathrm{C}$ with soakin time time for 5 hours,. Fatigue strength test results are shown in Figure 4 and Figure 5. At Figure 4 and 5 shows that the untreated specimen has 1,54E+03, the highest number of cycles because there has been no addition of carbon on the surface of the specimen. Specimens treated pack carburizing have greater hardness number compared with this untreated due to the presence of activated carbon and supported by the addition of (PMSP) as energizers so that faster carbon diffuses into the material surface. Pack carburizing process with carburizer media composition $30 \%$ (PMSP) shell powder has the highest surface hardness number, but the lowest cycles number of fatigue (less than 1,54E+03). In the process of pack carburizing if the percentage of (PMSP) increased then the carbon diffuses to the steel will be faster and make the surface hardness number of structural steel will be greater, so the carbon will more easily diffuse between the gaps $\mathrm{Fe}$ atom. In Figure 4 and 5. appointed that the fatigue strength of specimens decreased due to pack carburizing process. The cycles number of fatigue of specimens that pack carburizing processing influenced temperature , time soaking and composition PMSP in carburizer media. The higher of the temperature, time soaking and composition of PMSP decreases the more cycles number of fatigue. 
International Journal of Advances in Scientific Research and Engineering (ijasre), Vol 5 (12), December-2019

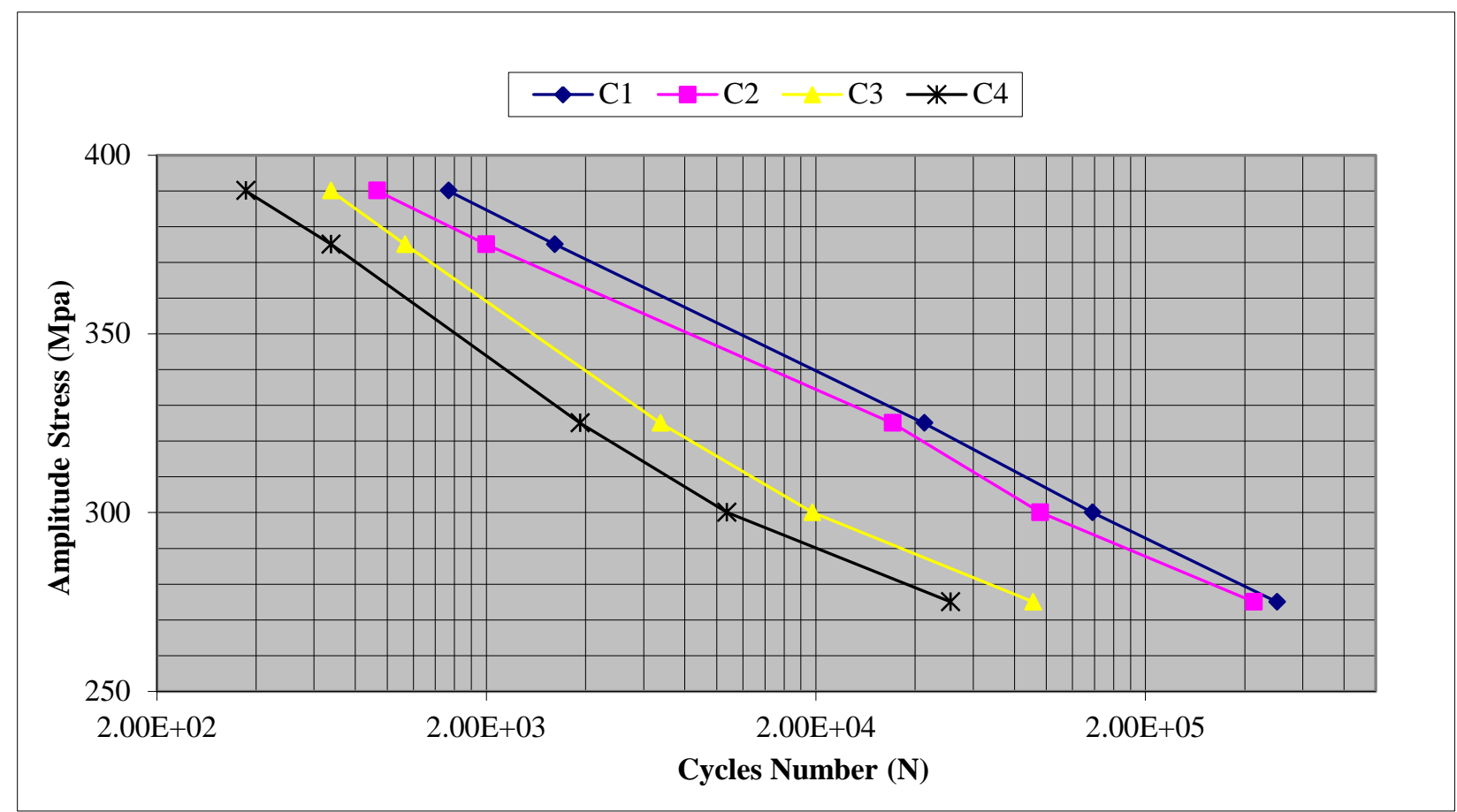

Figure 4. S-N curve of specimens on pack carburizing at temperature $800^{\circ} \mathrm{C}$ and soaking time 5 hours

C1 : untreated

$\mathrm{C} 2: 10 \%$ (PMSP) : $90 \%$ (TWC)

$\mathrm{C} 3: 20 \%$ (PMSP) : $80 \%$ TWC

$\mathrm{C} 4: 30 \%$ (PMSP) : 70\% TWC

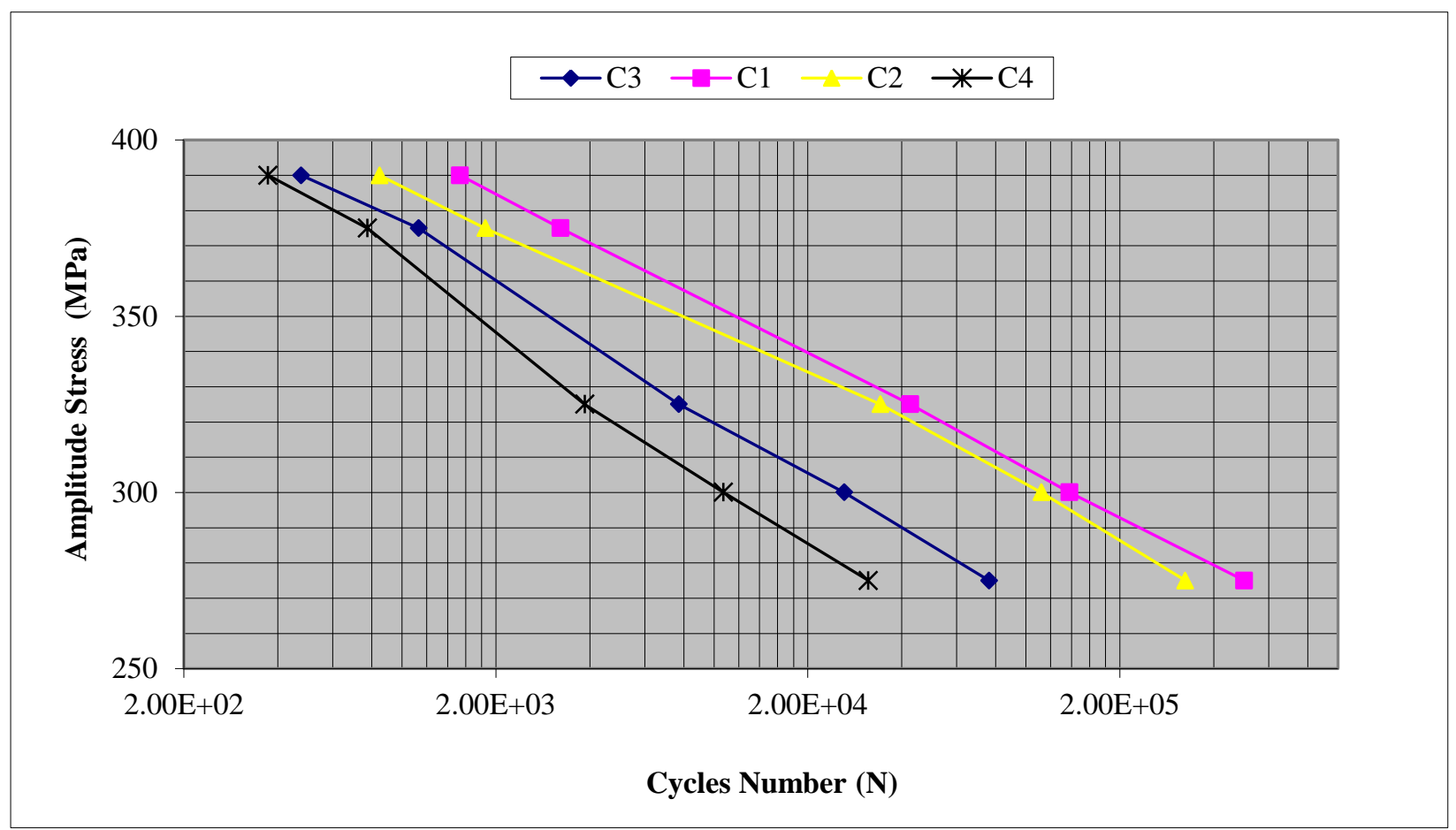

Figure 5. S-N curve of specimens on pack carburizing at temperature $950^{\circ} \mathrm{C}$ and soaking time 5 hours 


\subsection{Microstructure Testing Result}

The microstructure observation of the initial material before pack carburizing process can be seen in Figure 6. Figure 6 . shows that the structure of ferrite (colored light and white) is more dominant than the structure of pearlite (colored dark and black). Structural SS 400 untreated low surface hardness number around $129 \mathrm{Kg} / \mathrm{mm}^{2}$ (1), but high ductility so that the cycles number of fatigue were large (high fatigue strength). The structure of pearlite and carbide is more than ferite, after pack carburizing proceses at temperature $800{ }^{\circ} \mathrm{C}$, soaking time for 5 hours and addition of PMSP with a $30 \%$. So that surface hardness number of the material becomes higher because there is addition of carbon element. While the carbide structure will enlarge because effect of heating in pack carburizing processes. Pack Carburizing process at temperature $950^{\circ} \mathrm{C}$ and soaking time for 5 hours causes intertisi diffusion of carbon on specimens surface. Addition of PMSP with a $30 \%$ composition as energizer can accelerate the process of carbon diffusion into the structural steel SS400 so that it can form more pearlit structures. In Figure 7 it is shown that the number of pearlite structures is increasing and the grain size is evenly distributed along the penetration although on the perlite side there is still a lot of ferrite. An increasing the number of pearlite structures more than the microstructure of the initial material may occur due to the effect of adding carbon elements to the material during the pack carburizing process. It makes the specimen harder but the fatigue strength (the cycles number of fatigue ) decreases. Figure 8 . it is shown that the maximum increase in pearllite compared to other microstructure on untreated and at temperature $800{ }^{\circ} \mathrm{C}, 30 \%$ PMSP composition in media carburizer. In addition, the penetration of carbon is also quite deep and the granules on pearlite size are larger than untreated. With larger grain size then the hardness number generated will also be larger. This is due to the comparison of additional material in the form of 70\% TWC and 30\% PMSP as energizer that can accelerate the process of carburization and supported by temperatur pack carburizing and soaking time. The heating $950{ }^{\circ} \mathrm{C}$ and soaking time for 5 hours, takes the diffusion of carbon into the surface steel becomes faster so that it can change the microstructure grains and the highest hardness value in comparison with the previous specimens, is shawn Figure 8. Also, This can increase the amount of carbon in the surface of specimens or carburizing layer.

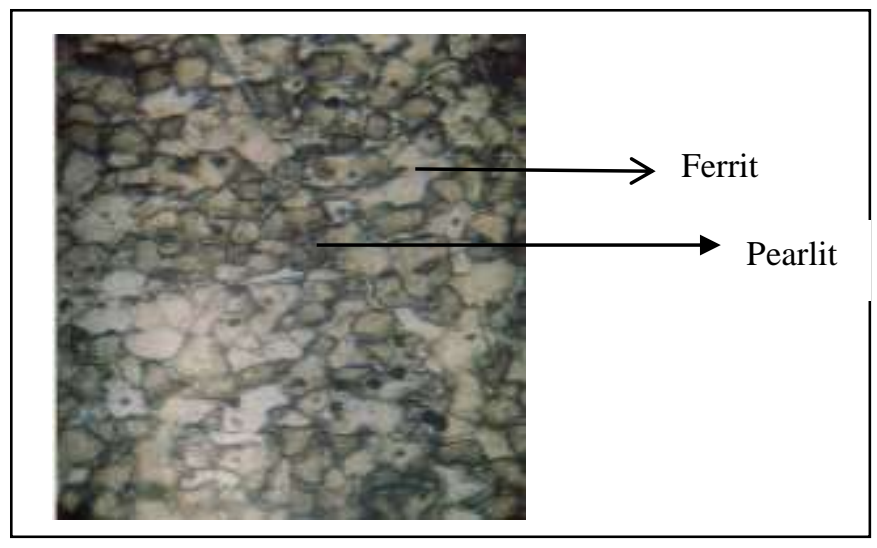

a

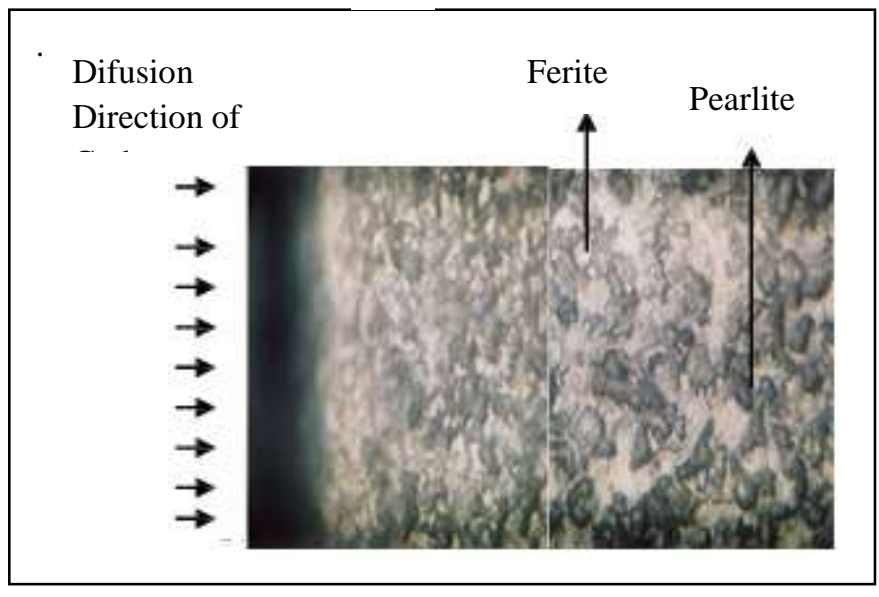

$\mathrm{b}$ 


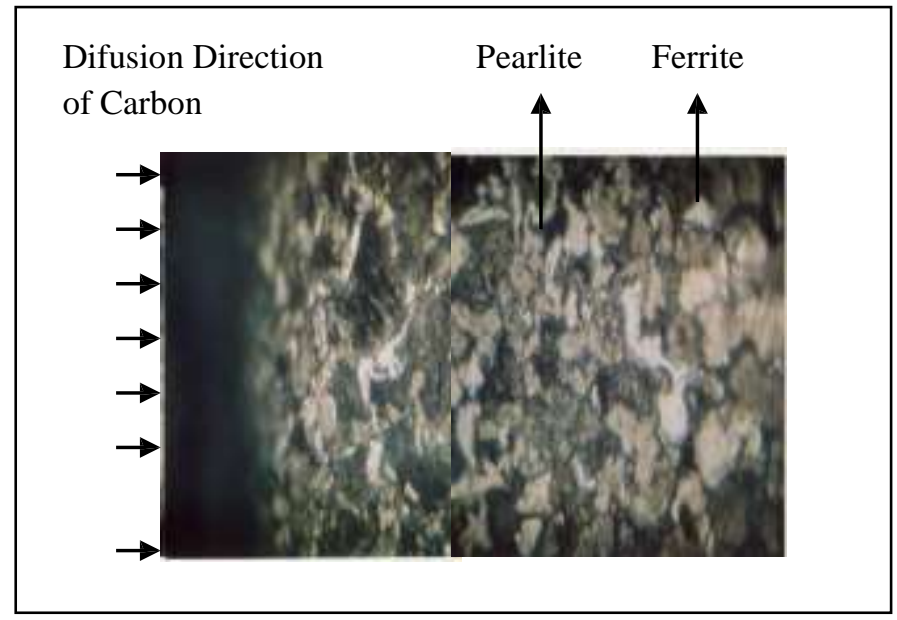

C

Figure 6. Microstructure of specimens on the pack carburizing proceses at soaking time for 5 hours a. untreated b. $30 \%$ PMSP at temperatur $800{ }^{\circ} \mathrm{C}$ c. $30 \%$ PMSP at temperatur $950{ }^{0} \mathrm{C}$

\section{CONCLUSION}

In conclusion, the addition of PMSP to the media carburizer in pack carburizing processes will increase the surface hardness number but decrease the fatigue strength (cycles number) low structural steel SS400. Carburizing agent with a composition of 30\% PMSP and 70\% TWC gives the highest increase in surface hardness number but the lowest fatigue strength. The cause is the formation of pearlite on the surface increasing, on pack carburizing at temperatur $950{ }^{\circ} \mathrm{C}$ and soaking time for 5 hours.

\section{ACKNOWLEDGMENT}

The authors thank Prof. Rudy Soenoko, Prof. Wahyono Suprapto are acknowledged for invaluable endless collaborations. Prof. I.G.N Wardhana Director Postgraduated Doctor Mechanical Engineering Program Brawijaya University permission to use of laboratory and other resource materials.

\section{REFERENCES}

1. Y. O. Aramide, S. A. Ibitoye, I. O. Oladele, and J. O. Borode, "Effects of Carburization Time and Temperature on the Mechanical Properties of Carburized Mild Steel, Using Activated Carbon as Carburizer," Materials. Research., vol. 12, no. 4, pp. 483-487, 2009.

2. F. O. Aramide, S. A. Ibitoye, and I. O. Oladele, "Pack Carburization of Mild Steel, using Pulverized Bone as Carburizer: Optimizing Process Parameters,” Leonardo Electronic Journal of Practices and Technologies ISSN 1583-1078 . Issue no. 16, pp. 1-12, 2010.

3. K. Miernik, R. Bogucki, and S. Pytel, "Effect of Quenching Techniques on The Mechanical Properties of Low Carbon Structural Steel," Arch. foundry Eng., vol. 10, no. 3, pp. 91-96, 2010.

4. S. Priyadarshini, T. Sharma, and G. Arora, "Effect of Post Carburizing Treatment on Hardness of Low Carbon Steel," Int. J. Adv. Mech. Eng., vol. 4, no. 7, pp. 763-766, 2014.

5. P. A. Ihom, "Case hardening of mild steel using cowbone as Energiser," African J. Eng. Research., vol. 1, no. October, pp. 97-101, 2013.

6. A. Oyetunji and S. O. Adeosun, "Effects of Carburizing Process Variables on Mechanical and Chemical Properties of Carburized Mild Steel," Pakistan J. Basic Appl. Sci., vol. 8, no. 2, pp. 1-7, 2012.

7. O. M. Oluwafemi, S. R. Oke, I. O. Otunniyi, and F. O. Aramide, "Effect of carburizing temperature and time on mechanical properties of AISI/SAE 1020 steel using carbonized palm kernel shell," Leonardo Electron. J. Pract. Technol., vol. 14, no. 27, pp. 41-56, 2015.

8. B. S. Saini and V. K. Gupta, "Fatigue crack propagation behaviour of some low alloy steels in case carburised condition," Int. J. Materials Engineering Innovation. vol. 3, no. September, pp. 330-339, 2012.

9. J. N. Sultan, "Effect of Austenizing and Tempering Heat Treatment Temperatures on the Fatigue Resistance of Carburized 16MnCr 5 ( ASTM 5117 ) Steel," Tikrit Journal of Engineering Sciences. vol. 20, no. 4, pp. 1-10, 2013. 
10. C. Paper, A. I. A. F. Consultation, C. E. Questions, I. U. View, and A. I. Al-mosawi, "Effect of carburizing on fatigue strength," no. February 2013, 2014.

11. Delvita, H., Djamas, D., dan Ramli. "Effect of Calcination Temperature Variation Against Characteristics Calsium Carbonat (CaCO3) in The Snail Shell (Pila ampullacea) Available in Pasaman District. Pillar Of Physics. Vol.6. Hal 17-24, 2015.

12. S. Khadijah et al., "Mechanical properties of paste carburized ASTM A516 steel," Procedia Eng., vol. 68, pp. 525-530, 2013.

13. S. Dhankhar and P. Khokhar, "Improvement in Hardness of Mild Steel with Methane Carburization," International Journal of Enhanced Research in Science Technology \& Engineering, ISSN: 2319-7463. vol. 4, no. 1, pp. 62-65, 2015.

14. J. Bryscejn, "push-pull loading," International Journal of Materials. vol. 1, no. 3, pp. 99-104, 2014.

15. S. Roy and S. Sundararajan, "Surface \& Coatings Technology The effect of heat treatment routes on the retained austenite and Tribomechanical properties of carburized AISI 8620 steel," Surf. Coat. Technol., vol. 308, pp. 236-243, 2016.

16. S. Coconut, S. Mixture, and R. Umunakwe, "Effects of Carburization with Palm Kernel Shell/Coconut Shell Mixture on the Tensile Properties and Case Hardness of Low...," FUOYE Journal of Engineering and Technology, Volume 2, Issue 1, March 2017. 